Article

\title{
Whither Shall We Go? The Past and Present of Black Churches and the Public Sphere
}

Kendra H. Barber

Department of Sociology, University of Maryland, College Park, 2112 Art-Sociology Building, College Park, MD 20742, USA; E-Mail: khbarber@umd.edu; Tel.: +1-301-405-3503

Academic Editor: Christine Soriea Sheikh

Received: 20 October 2014 / Accepted: 10 March 2015 / Published: 18 March 2015

\begin{abstract}
In this paper, I analyze the contemporary role of the Black Church in the public sphere. Some argue that despite the historical role of the Black Church in addressing racial inequality, it should not be involved in the public sphere, as there should be a clear separation between church and state. I argue that black churches are filling a gap created by the self-help ideology of a neo-liberal era where addressing the outcomes of contemporary racial inequality is left to private sector organizations, such as churches, rather than the federal government. I assert that the Black Church should remain engaged in the public sphere for two reasons: first, black churches are operating in the absence of state welfare rather than as an alternative to it and second, black churches are among the few institutions providing race-specific remedies that have been abandoned in a colorblind era.
\end{abstract}

Keywords: black church; race/ethnicity; religion; public engagement; neoliberalism

\section{Introduction}

For over a century, scholars such as W.E.B. Du Bois, Carter G. Woodson, Benjamin Mays, E. Franklin Frazier, C. Eric Lincoln, and others have studied the role of the Black Church ${ }^{1}$ in the lives of African Americans. As the first institution created by and for African Americans, the Black Church has

1 I use "the Black Church" in the same vein as Lincoln and Mamiya [1] to refer to the shared historical origins and culture among churches belonging to the historically black denominations. My goal is not to assume that the Black Church is a monolith, but rather to highlight the difference between a collective of institutions with a common sociohistorical identity and individual churches that have a predominately black membership, but may not share that sociohistorical identity. 
been considered "the social centre of Negro life in the United States" ([2], p. 136) and a "refuge in a hostile world" ([3], p. 45). These positive characterizations notwithstanding, the role of the Black Church as understood by scholars has not been without contention. Some have denounced the Black Church for upholding the status quo of race, class, and gender oppression [3-5], while others have characterized the Black Church as liberatory and providing African Americans with the spiritual and social tools to challenge oppression [6-8].

In this paper I analyze the role of the Black Church in black communities - particularly as it relates to providing resources and opportunities in a racially unequal society. I argue that black churches are filling a gap created by the self-help ideology of a neo-liberal era where addressing the outcomes of contemporary racial inequality is often left to private sector organizations, such as churches, rather than the federal government. I begin by explaining the social science debate on the role of the Black Church as being variously accommodative to the status quo, resistant to the status quo, or both simultaneously. I argue that the accommodative/resistant binary used to categorize the Black Church is limiting for three reasons: first, it misrepresents the complex history of black churches; secondly, it ignores how churches may move within that binary due to social and historical circumstances; and thirdly, binaries create a hierarchy in which one category is assigned a higher value than the other. Subsequently, I historically situate the function of the Black Church in addressing racial inequality from the "invisible institution" of slavery to the present. Finally, I address arguments that oppose the public engagement of black churches. Here I define public engagement as activities that seek to improve social problems, including protest politics, electoral activism, and community development [9]. While I will not argue that black churches are the best or only institutions to address racial inequality, I will assert that they should remain engaged in the public sphere for two reasons: first, black churches are operating in the absence of state welfare rather than as an alternative to it and secondly, black churches are among the few institutions providing race-specific remedies that have been abandoned in a colorblind era.

\section{Contradictory Institutions? The Social Science Debate on the Role of Black Churches}

The scholarship on the role of black churches can be described as ambivalent at best and contradictory at worst. Prior to the late 20th century, most of this literature fell into a dichotomy of characterizing the role of black churches as being either an opiate or accommodative to the oppressive status quo, or liberatory and resistant to the status quo of oppression. The accommodative half of the dichotomy refers to black churches that ignored or downplayed inequality and accepted the normative claims and practices of white society [1,10]. For example, black churches during the Reconstruction era (typically defined as the years from 1865-1877) have been characterized as accommodative due to their acceptance of the prevailing Victorian standards of morality and calls for assimilation into white society. Numerous churches, particularly in the National Baptist Convention, created temperance organizations to counter vices that presented stereotypical images of blacks to whites.

The resistant half of the dichotomy refers to black churches that viewed Christianity as a mechanism for liberation, affirmed their black heritage, and challenged the status quo of inequality $[1,10]$. Historically, resistance has referred to protest, community action, and political involvement [10]. For example, contrary to the narrative that the majority of black churches supported Dr. Martin Luther King, Jr. 
and the Civil Rights Movement, it was actually a minority of churches [11]. The minority of churches that broke off from the National Baptist Convention to join the newly formed Progressive National Baptist Convention are examples of the resistant side of the dichotomy. The Progressive National Baptist Convention was actively involved in the Civil Rights Movement, supported the Black Power Movement, and was one of the earliest groups to oppose the Vietnam War [1].

Leading up to the Civil Rights Movement, scholars tended to agree that religion did little to address racial inequality among blacks and that black churches were more accommodating than resistant. While W.E.B. Du Bois acknowledged that one function of organized religion in black communities was to provide a sense of community and shelter from racism in the outside world, he also observed how black churches could simultaneously uphold the status quo of race, class, and gender oppression by reinforcing divisions based on economics, not challenging Jim Crow segregation, and denying women access to leadership positions [12]. In his 1944 report on race relations in the United States, An American Dilemma, Myrdal [13] stated that although some black ministers took part in protesting racism, on the whole black churches were conservative institutions and black ministers were lacking in education. E. Franklin Frazier was one of the harshest critics of the Black Church. In The Negro Church in America, published in 1963, Frazier blamed black churches for undermining intellectual thought, leading to the "so-called backwardness of American Negros" ([3], p. 86). It would only be through a process of secularization, whereby the Black Church lessened its otherworldly outlook and focused more upon the social condition of blacks, that Frazier believed there would be the potential to address racial inequality.

While accommodation has a submissive tone of uncritical acceptance, it is important to question this one-dimensional characterization of accommodation. By assuming that accommodation can never be subversive, scholars neglect how black churches may have been more accommodative as a survival strategy. For example, black churches during the Reconstruction era have been characterized as accommodationist because of their emphasis on Victorian morality and assimilation into white society, symbolized by the language of "racial uplift" and self-help. Racial uplift involved moral, economic, social, and educational improvement, which overlapped with Victorian morals that stressed self-discipline, low tolerance of crime, sexual restraint, and in general "respectable" (i.e., middle-class) behavior [14]. In many post-Civil War black churches, blacks were encouraged to abstain from alcohol and tobacco and become educated. On the one hand, this behavior upheld white, middle-class values. On the other hand, by encouraging blacks to present themselves as citizens worthy of equal treatment, the seemingly accommodative behavior of some black churches actually challenged the dominant narrative that blacks were uncivilized and would never participate as equal members of the United States democracy [14]. It is also important to note that in a context in which black churches faced violent consequences for challenging the status quo, such as church burnings and bombings ${ }^{2}$, they "represented not an escapist and other-worldly orientation" that is focused on heaven, "but the only viable bastion of a community under assault" ([16], p. 5).

Beginning with the Civil Rights Movement, scholars began to debate the accommodative role of black churches in addressing racial inequality. It is significant to note that this shift in the literature,

2 According to Soule and Van Dyke [15], in the 1960s there were more than 300 church bombings in the United States and between 1989 and 1996 more than 200 black and multiracial churches were burned. 
and this particular historical juncture, has shaped our contemporary narrative of the Black Church. Before this point, scholars argued that the Black Church was primarily an accommodative institution. When the Black Church is criticized for its perceived lack of activism, there is an assumption that the Black Church has always been defined as a resistant institution and is now abandoning that lineage. Yet, it was only about 60 years ago that scholars began to construct a narrative of the Black Church as a resistant institution. The result of this debate among scholars was a very contradictory assessment in which some scholars continued to argue that black churches were accommodative, while others argued they were liberatory. Gary Marx [4] posited that the Black church functions as an opiate that stifles public engagement. He found that an otherworldly focus tends to stifle civil rights militancy, and traditionally black denominations (e.g., National Baptist Convention) were less militant than black churches in traditionally white denominations (e.g., Episcopalian). Revisiting the history of the Black Church in the United States, theologian James Cone disputed the accommodationist thesis and suggested that liberation is central to the religious history of blacks. He declared, "Freedom and equality made up the central theme of the black church; and protest and action were the early marks of its uniqueness" ([6], p. 94). Like Cone, Wilmore [6] viewed black religion as inherently radical because of its preoccupation with liberation from oppression. In his analysis of the role of black churches during the Civil Rights Movement, Morris ([8], p. 77) maintained that they provided organization and leadership to the Civil Rights Movement as well as "an ideological framework through which passive attitudes were transformed into collective consciousness supportive of collective action". Yet, the participation of some black churches in the Civil Rights Movement did not completely dismiss the accommodationist perspective. For example, in The Jesse Jackson Phenomenon, Reed [6] contested that instead of encouraging political mobilization, black churches are by nature anti-political and more likely serve as a force of social control. It was not until the 1990s with the publication of Lincoln and Mamiya's The Black Church in the African American Experience that scholars began to recognize that the Black Church could function as both accommodative and resistant simultaneously, rather than as a dichotomy.

The Black Church is at times a contradictory institution with a complex history. Baer and Singer [17] describe the complex nature of black churches that, on the one hand, exhibited an accommodative stance to racism by trying to shield blacks from a racist society and, on the other hand, simultaneously demonstrated a resistive stance by engaging in broader social change from the Abolition Movement to the Civil Rights Movement.

For example, Booker T. Washington ([18], p. 22) criticized the seemingly otherworldly nature of black religious life arguing that the Black Church "must be recalled from its apocalyptic vision back to the earth". Yet, in Domination and the Arts of Resistance Scott [19] discloses that during this time, slaves were creating subversive "hidden transcripts" that challenged their oppressed conditions. He describes a hidden transcript as any discourse or act that takes place beyond the observation of those in power that mocks, contradicts, or challenges those who hold power. The theology that enslaved blacks produced when they gathered together was a hidden transcript that opposed their oppressed conditions. Scott [19] also reveals that they created "public transcripts" that presented a meaning that would appear to support the status quo but actually had an entirely different and oppositional meaning. For example, spirituals such as "Steal Away to Jesus" or "Go Down Moses" may have appeared to whites as a fascination with heaven and the Bible that kept their slaves obedient, but they often had subversive 
meanings that slave owners did not realize. The lyrics "Steal away, steal away, steal away to Jesus. Steal away, steal away, steal away home. I ain't got long to stay here. My Lord He calls me" may, on the surface, appear to be a desire to be in heaven. However, these lyrics simultaneously communicate a message that encouraged slaves to flee their oppressive conditions.

A second limitation of the accommodative/resistant binary is that the historical dynamism of churches due to social and historical circumstances is missed [1]. Interestingly, Booker T. Washington made this same critique over one century ago. In his 1905 article "The Religious Life of the Negro" Washington ([18], p. 20) begins by stating:

In everything that I have been able to read about the religious life of the Negro, it has seemed to me that writers have been too much disposed to treat of it as something fixed and unchanging. They have not sufficiently emphasized the fact that the Negro people, in respect to their religious life, have been, almost since they landed in America, in a process of change and growth.

The Black Church, as Washington noted, does not exist in a vacuum. It has always been in an interdependent relationship with the socio-political context of the time. For example, during the late 1960s the United States was experiencing the emerging Black Power Movement in the aftermath of simultaneous Civil Rights legislative victories and the assassinations of black political leaders. In this socio-political context, a very radical orientation emerged from some black churches. While it reached its apogee with the writings of James Cone, black liberation theology was born out of a context of disillusionment with the Civil Rights Movement and continued race and class oppression. The context of this time period shaped a stance where some black pastors argued that churches could not separate religion and black liberation. While not all black churches subscribed to black liberation theology, its emergence was influenced by the sociopolitical context. Therefore, it is misleading to say that the Black Church has always been accommodative or resistant because the Black Church does not exist in a static context.

The final limitation of the accommodative/resistant binary is that it creates a hierarchy in which one category is assigned a more positive value than another and allows scholars to transmit their own perspectives. Scholars who previously criticized the Black Church for an overly accommodative role did so with the perspective that resistance was more favorable than accommodation, the only acceptable way to address racial inequality, and represented the paradigmatic Black Church [20]. The problem this presents is that these either/or categories are mutually exclusive. Therefore, a binary categorization leaves no room for black churches to be both accommodative and resistant. An accommodationist understanding of the Black Church is informed by a resistant understanding of the Black Church because they are always defined in contrast to each other. If a resistant church is characterized by social and political activism and an affirmation of black racial identity, then an accommodative church is characterized as lacking that. Binaries allow for neat, mutually exclusive categorizations even if the categories are not very neat in reality. In general, the Black Church has always defied binary categorization, simultaneously challenging oppressive conditions while supporting 
some dimensions of them - at times even perpetuating oppression such as sexism and heterosexism within their congregations ${ }^{3}$.

More recent studies have moved beyond the simplistic binary of the role of the Black Church in addressing racial inequality as either accommodative or resistant. In their seminal work, The Black Church and the African American Experience, Lincoln and Mamiya [1] suggest six dialectical models that represent the simultaneous tensions that exist in black churches as agents of change or keepers of the status quo. Dialectical tensions hold two "polar opposites in tension, constantly shifting between the polarities in historical time" ([1], p. 11). Whereas binaries are two components that are mutually exclusive, dialectical tensions are more representative of a spectrum with opposite polarities. The six dialectical models are: (1) priestly and prophetic, where priestly represents church activities geared toward the spiritual life of attendees and prophetic represents church activities geared toward the wider community; (2) other-worldly and this-worldly, where other-worldly represents a heaven-focused orientation and this-worldly represents an orientation focused on the affairs of the here and now; (3) universalism and particularism, where universalism represents a colorblind Christian message and particularism represents black consciousness emerging out of a past racial history; (4) communal and privatistic, where communal represents churches being involved in all aspects of the lives of attendees and privatistic represents a narrow focus on the religious needs of attendees; (5) charismatic and bureaucratic, where charismatic represents investing more authority in the charisma and personality of preachers than in bureaucratic hierarchy; and (6) resistance and accommodation, where resistance represents affirming black heritage and accommodation represents being influenced by the norms and values of white society.

Lincoln and Mamiya's [1] dialectical models explain how one end of the continuum or the other may become more dominant in a particular church or at a particular time in history. In addition to moving beyond a binary, the main contribution of Lincoln and Mamiya's dialectical models are that they allow for change over time rather than presenting the Black Church as a fixed entity that does not change. The Black Church has been in existence for centuries and over the course of that time it has changed based on the sociopolitical context of the time. Furthermore, Lincoln and Mamiya expanded the accommodative/resistant characterization of the Black Church to include other dialectics related to how the Black Church may approach racial inequality. Although Lincoln and Mamiya's dialectical models served as a paradigm shift from the prevailing dichotomous understanding of the Black Church, they simply stretch various dichotomies into a series of continuums. These dialectical models do not account for the ways in which the opposite spectrums of each dialectical model would interact with or shape each other.

Higginbotham [16] asserts that, rather than dialectical tensions, the Black Church embodies a dialogical model. Whereas Lincoln and Mamiya [1] describe the dialectical tensions as polarities that do not achieve synthesis, Higginbotham's dialogic model accounts for the presence of constant interaction and how this interaction causes the polarities to shape each other. In dialectical tensions, one polarity eventually becomes more prominent than another, although this primacy can shift over time. A dialogical model focuses on how the polarities mutually produce each other. For example, in

3 See Douglass [21] for more on heterosexism in the Black Church and Grant [22], Tucker-Worgs and Worgs [23] for more on same-sex marriage and the Black Church, and Williams [24] for more on sexism in the Black Church. 
her study of women in black Baptist churches, Higginbotham reveals that while Black Church values gave meaning to the private sphere of the family, these same church values generated the largest number of voluntary organizations in the black community. Thus, the Black Church created a dialogic relationship between black women's faith and secular social activism. Higginbotham ([16], p. 17) states, "This complexity precludes attempts to bifurcate black women's activities neatly into dichotomous categories such as religious versus secular, private versus public, or accommodation versus resistance." Higginbotham argues that the Black Church represented a realm where the sacred and secular did not operate as separate and individual tensions, but rather interacted and informed each other. It is this aspect of the dialogic relationship that recognizes interaction between the Black Church and the black public sphere that I argue continues to inform the role of black churches today in addressing racial inequality.

Although Higginbotham's [16] dialogic argument is the most recent theory since Lincoln and Mamiya's [1] dialectical argument, her dialogic argument lacks the popularity and widespread adoption of the dialectic theory. The contribution of Higginbotham's dialogic is that, unlike the dialectical model, it allows for an exploration of how there may be interaction between the polarities. For example, Lincoln and Mamiya's resistance and accommodation dialectic is useful for explaining that black churches can shift between these polarities over time, but it is less useful for explaining how resistance may be shaped by accommodation or vice versa. As an illustration, the racial uplift initiatives of the post-Reconstruction Black Church that included following Victorian values to accommodate blacks to white society were also shaped by a self-help tradition that resisted white narratives that blacks were not respectable citizens deserving of rights.

By analyzing the contradictory characterization of black churches, it is evident that the Black Church will continue to embody this tension. Knowing that the Black Church is a complex and contradictory institution, what should be our expectations of its role in public engagement? Whether scholars were arguing that the Black Church was too accommodative or resisting oppression, the consensus was, and remains, that at its best the Black Church should be a socially active and progressive institution [20]. However, as Washington ([25], p. ii) suggests, I will argue that the role of the Black Church "can be comprehended best by zeroing in on what is rather than what ought to be" (emphasis mine). This approach involves evaluating the role of the Black Church over time in addressing racial inequality. The following section will focus on this in order to assess the potential role of the Black Church in public engagement.

\section{Historicizing the Public Role of the Black Church in Addressing Racial Inequality (18th-21st Centuries)}

The goal of this section is not to provide a comprehensive history of the Black Church in the United States. Rather, the goal is to summarize the function of the Black Church in addressing racial inequality with an emphasis on the presence of dialogic relationships in various time periods. What emerges from this overview of the public engagement of the Black Church is that a variety of strategies have been undertaken to address racial inequality. Furthermore, the Black Church has often had to fill in the gap of providing services to the black community out of necessity. 


\subsection{From the Invisible Institution of Slavery to Reconstruction (1700s-1877)}

During slavery, blacks met in "invisible institutions" [26], or private meetings in the woods or slave quarters, and created an "underground theology" [27]. These invisible institutions were characteristic of a dialogic relationship. Raboteau [26] explains that enslaved blacks shaped Christianity to their own particular experience while simultaneously the symbols and values of Christianity helped shape the slave community's image of itself. To illustrate, enslaved blacks created religious songs that reflected their experience of enslavement such as "Didn't My Lord Deliver Daniel?" At the same time, enslaved blacks interpreted the Biblical stories of bondage and freedom in Exodus as a counter-narrative against their "God ordained" enslavement.

During Reconstruction, black churches became more than just religious institutions; they were autonomous social institutions as well. From schools to meeting halls to social clubs to community kitchens, black churches served every role needed by the newly emancipated community. Now that physical emancipation had been achieved, black churches looked to address racial and economic oppression. They stepped in where the government lacked the means or simply failed blacks, and gathered resources to provide black families with food, clothing, shelter, land, and education. Black ministers filled multiple roles and over one hundred were elected to political office during Reconstruction [28]. The political activities black churches engaged in could occasionally create problems for their congregations, who would sometimes find their churches burned down by whites who felt they upset the status quo [29].

Although black churches were cornerstones of the black community, they were by no means homogenous in their responses to the trials and tribulations faced by African Americans. Some black ministers continued to preach messages of liberation to their congregations, trusting that God was on their side in the battle against racism and poverty, while others - particularly ministers with middle-class black congregations - preached messages of compromise and accommodation.

\subsection{The Black Church and Jim Crow (1877-1940s)}

Scholars have characterized churches in the post-Civil War era as being more accommodationist due to their emphasis on uplift and assimilating to white society $[3,14]$. Yet, the Black Church is an institution informed by the social, political, and economic contexts surrounding it. Post-Reconstruction black Baptist churchwomen felt it was their duty to indoctrinate blacks with middle-class, Victorian values - now referred to as "the politics of respectability" - in order to defy messages of the cultural and intellectual inferiority of blacks. The black Baptist women's conventions, for example, conducted motherhood classes, temperance crusades, and raised money to build schools [16]. This characterization of accommodation is misleading and masks the ways in which the emphasis on racial uplift embodied not only acquiescence to the values of white society but also the potential to be equals rather than subordinates to whites [14]. This emphasis on racial uplift was part of the black self-help tradition that emerged in this changing sociopolitical context due to Post-Reconstruction Republicans abandoning the cause of racial justice for freed blacks [30]. As previously stated, this represented a dialogic relationship in which the accommodation to Victorian values and the politics of respectability was shaped by a desire to resist stereotypes of blacks that justified their marginalization in society. 
During the Great Migration - the exodus of approximately seven million blacks out of the rural South into cities of the North, Midwest, and West from 1910 to 1970 - urban churches grew and were overwhelmed with poor and undereducated migrants. Some black churches worked as "cultural brokers" to help rural blacks transition to urban life, similar to the role undertaken by post-emancipation black churches [1]. They established programs to address the educational, recreational, economic, and political needs of the new arrivals. However, large-scale social outreach was the exception rather than the rule and the needs exceeded the capacity of many churches to serve them.

The 1920s-1930s were a period Wilmore [7] refers to as the deradicalization of the Black Church. With the country in a severe economic depression, little improvement in racial injustice, and an influx of Southern migrants, alternative religious movements emerged to address the social and spiritual needs of blacks. Some of these movements reflected a more otherworldly orientation but were racially separatist groups, such as the Nation of Islam. Contrary to contemporary understandings of the Nation of Islam as a highly political group, the Nation of Islam was very otherworldly in outlook and only became politically active through the work of Malcolm X, against the wishes of Elijah Muhammad, the leader of the Nation of Islam [31]. Other movements were equally otherworldly, but were multiracial, such as Father Divine's Peace Mission and Charles Manuel "Sweet Daddy" Grace's House of Prayer for All Peoples. Although Father Divine and "Sweet Daddy" Grace were known for their flamboyant lifestyle and were accused of taking advantage of their mostly poor followers, both also provided social services for followers, such as food banks, affordable housing, and daycares [32].

\subsection{The Black Church and the Civil Rights Movement (1950s-1960s)}

At a time when scholars such as Gunnar Myrdal and E. Franklin Frazier were predicting its demise, the Civil Rights Movement illuminated the liberatory potential of the Black Church. While only a minority of black churches participated, Morris [7] illustrates the indispensable role those black churches played in providing resources for the growing desegregation movement. Black churches provided the leadership and membership base for organizations such as the Montgomery Improvement Association (MIA) and Southern Christian Leadership Conference (SCLC), financial support, meeting spaces, and communication networks $[8,33]$.

The most prominent leader of the Civil Rights Movement, Dr. Martin Luther King Jr., represented the dialogic relationship between faith and action. He used the social gospel ${ }^{4}$, which shaped many black churches, to interpret democracy in the United States [35]. He also used democracy in the United States to interpret the legitimacy of the movement. This social gospel perspective, which viewed racial and economic oppression as social evils that Christians had a moral duty to resist, led King to view the church as equally instrumental to both individual and social salvation.

4 The social gospel movement is a religious movement that began in the late 19th century in response to social problems such as urban poverty, child labor, and low wages. Inspired by New Testament passages that present Christ as a challenger of the status quo, the social gospel developed in response to traditional theological ideas that stressed individual sin rather than socioeconomic justice. Key features of social gospel include: a stance informed by the life of Christ, prophetic leadership concerned about the less fortunate, knowledge of social problems, a connection between Christianity and social and political activism, and the desire to combat inequality through social reform [34]. 
The combination of the social gospel and traditions of the Black Church even influenced the development of other organizations such as the Student Nonviolent Coordinating Committee (SNCC) [11]. The religious beliefs of activists sustained the movement in the face of violence and emboldened individuals to stand up to a white supremacist system.

\subsection{Black Power and Liberation Theology (1960s-1970s)}

The demands made on the United States government by those involved in the Civil Rights Movement resulted in legislative victories such as the Civil Rights Act of 1964 and the Voting Rights Act of 1965. However, with the assassination of Dr. King, frustration with the methods and pace of change materialized into a movement that advocated for black power, which argued against integration as a solution for racial inequality. This new black consciousness created a paradigm shift from the Negro Church, studied by E. Franklin Frazier, to the "bold, strident, self-conscious phoenix that is the contemporary Black Church" ([36], pp. 105-106).

Black liberation theology emerged from pastors who were interested in articulating a more radical side of the Black Church. Black liberation theology's sole purpose is to "apply the freeing power of the gospel to black people under white oppression" ([6], p. 31). The primary articulator of this theology was James Cone, who called on churches to break with white theology and recognize that "where there is black, there is oppression" therefore, "Christ is black because he is oppressed, and oppressed because he is black" ([6], p. 69). Cone advocated a dialogic relationship between the theory of black liberation theology and the practice of black power to aid in the self-determination and liberation of blacks to help them achieve equality with whites rather than accommodating to them. While black liberation theology did not always translate into social programs, it represented a type of political consciousness raising that emphasized a form of Black Nationalism that had not been present in the Black Church since the period immediately after Reconstruction.

One of the strategies to address racial inequality used by black churches during the late 1960s-1970s was through non-profit Community Development Corporations [CDCs]. CDCs are nonprofit organizations whose mission is to fulfill some aspect of community development. Their goals are to help individuals who lack economic and social resources and correct structural injustices [37]. A church CDC is different from a church ministry in that while CDCs are affiliated with the church, they are separate nonprofit organizations that are focused on outreach, and they are usually professionally staffed by paid workers. Ministries, on the other hand, are volunteer-based and financed by and run out of the church. CDCs first emerged in the 1960s and can be characterized as having three waves - the 1960s, the 1980s, and post 1980s. The first wave of CDCs in the 1960s were often affiliated with black churches and were founded by community activists involved in the Civil Rights and Black Power movements. These CDCs grew out of neighborhood organizing in response to redlining, urban renewal, and urban riots. The Bedford-Stuyvesant Restoration Corporation in Brooklyn, New York is an example of a first-wave CDC that still exists and was developed in 1967 when Senator Robert Kennedy saw the deterioration that had occurred in the Bedford-Stuyvesant section of Brooklyn.

Although the first wave of CDCs emerged during the same time period of black liberation theology, CDCs were not a direct result of black liberation theology. Yet, we can postulate that because black liberation theology emphasized Black Nationalism and provided theological support to challenge racial 
inequality, this first wave of CDCs may have been influenced by black liberation theology. The Opportunities Industrialization Center formed by the Reverend Leon Sullivan of Zion Baptist Church in Philadelphia is an example of a religiously affiliated CDC modeled after the boycotting tactics of the Civil Rights Movement [37]. Reverend Sullivan organized hundreds of clergy and their congregations to boycott any companies that refused to provide job opportunities to minority youth and established job training programs through his CDC.

\subsection{Religious Neo-Liberalism (1980s-Present)}

The development of religiously affiliated CDCs in the late 1970s to early 1980s occurred during a time period of an increasing public presence of religious institutions, or what Casanova [38] refers to as the "deprivatization" of religion where religious institutions were less willing to be relegated to the private sphere. This also occurred within a political context in which conservatives began to demand that nonprofits assume a greater responsibility for social services without government support. President Ronald Reagan argued that federal spending on social services was too high and advocated a policy of less government intervention. His successor, President George H.W. Bush, championed the capacity of private sector voluntarism to solve social problems. Hence, there has been a clear trend since the 1980s of increasing the responsibility of religious institutions to provide the nation's social services [39]. At the same time that religiously delivered welfare has increased, secular welfare has decreased. While those who argue for the dismantling of the welfare state (neoliberals) are not the same group of people who argue for religiously-sponsored welfare (religious conservatives), the two groups have become somewhat bonded based on overlapping conservative desires. The core idea of neoliberalism "is not that government should contract out all its social assistance functions, but rather that it should completely devolve responsibility to the nonprofit sector (with little or no government funding)" ([40], p. 123). Religious conservatives such as President George W. Bush, on the other hand, are motivated by "compassionate conservatism" and the desire to sort the "deserving" needy from the "undeserving" needy. Both neoliberals and religious conservatives desire fewer government-sponsored "handouts". While neither neoliberal nor religious conservative ideas are new, they became increasingly popular by the $1980 \mathrm{~s}$. The merger of religious conservatism and neoliberalism is referred to as "religious neoliberalism" [40].

The philosophy of religious neoliberalism became a political reality with the expansion of "Charitable Choice". The Personal Responsibility and Work Opportunity Reconciliation Act (PRWORA) of 1996 ended Aid to Families with Dependent Children (AFDC) and made welfare much more difficult to obtain and keep. Charitable Choice was a provision of the 1996 welfare reform signed into law by President Bill Clinton that allowed states or counties to contract with religious-based organizations to provide services such as food, work, medical care, and maternity homes [39]. President George W. Bush expanded this by creating the White House Office of Faith-Based and Community Initiatives, which continued under President Barack Obama as the White House Office of Faith-Based and Neighborhood Partnerships.

While the call for religious institutions to provide social services may have appeared to be a new trend, the Black Church had been engaged in providing social services to the black community since its inception. The Black Church fulfilled the role of a mediating structure, defined by Berger and 
Neuhaus [41] as an institution that provides a linkage between large bureaucratic "megastructures" and individual citizens. This framework of mediating institutions provides the basis for the increased reliance on churches to provide social services. Members of individual congregations had always funded these social services, but with the United States government sanctioning the blurring of church-state boundaries, black churches were now in a position to compete for government funding for their services. Research by Chaves [42] indicates that black churches were five times more likely than other congregations to seek government funds. Nonetheless, some black churches refused to accept government funds because they feared it would decrease their autonomy and prophetic voice, as it is much more difficult to criticize the government while accepting its money [43].

In addition to receiving federal funding through charitable choice for their services, black churches continued to establish CDCs. The second wave of CDCs in the 1980s was less connected to community organizing, offered fewer social services and mainly engaged in housing development. For example, Allen A.M.E. Church in Queens, New York built a 300 unit apartment complex for the elderly in 1980 with federal housing loans [39]. CDCs established since the 1980s are the third wave, and they focus on commercial development and affordable housing. They are also more likely to be led by professionals rather than activists. In spite of cuts to federal funding under the Reagan and Bush administrations, CDCs continued to grow. Black church-affiliated CDCs have increased since 1989, partly in response to the needs of black inner-city communities that have experienced the flight of black middle-class residents as well as neoconservative policies. Yet, CDCs are not without their critics who argue that they carry out the agenda of business and political leaders rather than community members [9].

\section{Conclusions: Black Churches and the Public Sphere}

There are tensions between classical liberalism, which emphasizes secularism, and neoliberalism, which advocates abandoning the welfare state and reliance on the private sector to provide services. The dictum of "separation of church and state" is undermined, ironically, by calls for a reliance upon the private sector - mainly religious institutions - to provide social services. As long as state sponsored welfare continues to diminish and religious institutions are expected to provide social services, the church cannot be kept outside of the public realm.

Critiques of the presence of the Black Church in the public sphere and its ability to address racial inequality are not new. In American Dilemma, published in 1944, Myrdal [13] noted a pathological situation of too many voluntary organizations in black communities that accomplish little compared to their numbers. More recently, in 2013, Pinn [35] views the church as the polluting agent of the public sphere. As the only scholar to devote a book to critiquing the role of the Black Church in the public sphere, Pinn [35] asserts that black churches are best suited to serve the private, spiritual needs of members rather than being involved in the public arena. He does not dispute the important role black churches have had in providing resources for a community oppressed by racial and economic injustice. However, Pinn [35] concludes that the personal morality of the church does not make for good public policy - for example, focusing on individual pathology rather than structural issues. He also argues that the Black Church is ill-equipped to make an impact on issues facing blacks in a sustained and consistent manner-for example, providing charity rather than instituting structural change. However, 
Pinn does not acknowledge that the government is also not free of moral judgments. To illustrate, in narratives regarding government welfare President Ronald Reagan crafted an image of the "welfare queen", a lazy, pathological black woman who has babies that white taxpayers subsidize [44,45]. The narrative that the government has used to dismantle the social services of the welfare state has been one of the pathology of individuals rather than about structural barriers that create a need for government aid. Hence, the government is not a neutral institution and, perhaps while not using the language of "sin", also relies on personal morality to determine public policy.

In spite of Pinn's arguments that the Black Church should remain relegated to the private rather than public sphere, Higginbotham [16] contends that the Black Church should remain engaged in the public sphere. At issue is the public dimension of the Black Church, not the religious dimension of the public realm. "This reversal shifts the emphasis from the prevalence of religious symbols and values in the organization of our social lives and in our political languages to the different ways public spaces have been "interpolated within black religious institutions"' ([46], p. 341). Due to the laws denying blacks access to public space, the Black Church became a foundation of the black public sphere. Because this public sphere was established in conflict with the dominant white society, we can think of the Black Church as a "counter-public sphere" [16]. The Black Church housed schools, libraries, meeting halls, restaurants, and athletic clubs that met the needs of the black community. More than a physical space, the Black Church also served as a site of public discourse. Even after laws provided blacks with access to public space, the Black Church remained a vital part of the black public sphere and continued to operate as a "mediating structure" between blacks and the racial state $[16,46]$. The dialogic relationship between the Black Church and the public sphere has existed since the creation of the Black Church in the 18th century. Whereas white churches have not had the burden of being the most stable and autonomous institution in an oppressed community, black churches have always been expected to have a public dimension [47]. So too, the sharp dichotomy between the secular and sacred realms, while an expected goal in a secular state, has not been the case historically with the Black Church and the black community. As long as there are blacks in need of social services and as long as the state continues to, at least in part, rely on the Black Church to provide these social services, the dichotomy that situates the Black Church entirely in the private sphere will continue to be false.

What Pinn [35] fails to account for in his critique is the trend in public divesting and increasing reliance on private institutions to do the work of the welfare state. Unlike most European countries where church social welfare programs are minimal because the provision of social services is legally mandated, in the United States, the provision of social services is increasingly left to the private sector [39]. The Black Church takes in billions of dollars annually and is, economically speaking, the largest institution in the black community ([48], p. 32). I assert that black churches should remain publicly engaged for two reasons: first, black churches are operating in the growing absence of state welfare rather than as an alternative to it and secondly, black churches are among the few institutions providing race-specific remedies that have been abandoned in a "colorblind" era. I will expand on each of these reasons below.

First, black churches have had longstanding civic traditions and have been providing social services in black communities for decades - and in the case of some churches, for over a century. Critics of the involvement of churches in the public sphere, and particularly faith-based and government partnerships, fear that faith-based organizations have an agenda to replace the welfare state. On the 
contrary, in his study of Habitat for Humanity, faith-based homeless missions, and the government's reliance on faith-based social services in the aftermath of Hurricane Katrina, Hackworth [40] reveals that these organizations predominately see themselves as an extension of the state rather than an alternative to it. In addition, many in the faith community criticized the change in welfare reform that signaled the conferral of greater responsibility for churches to reduce welfare dependency and poverty [49]. Further, Chaves [50] notes that black churches are usually not attempting to provide an alternative to secular social services, but rather are usually working in collaboration with them. I argue that the disinvestment in black communities and decreasing state welfare has put black churches in a position where they provide services in the absence of the state.

Disinvestment "involves the systematic withdrawal of capital (the lifeblood of the housing market) and the neglect of public services such as schools; building, street, and park maintenance; garbage collection; and transportation" ([51], p. 5). Decades of discriminatory housing and loan policies, beginning in the 1940s, undervalued housing in black neighborhoods and led to the creation of black ghettos [52]. Beginning in the 1970s the disappearance of factory jobs that had once been plentiful in urban areas led to immense unemployment [53]. The repeal of desegregation programs in the 1980s resegregated schools [54]. Finally, the targeting of black and Latino communities in the War on Drugs in the 1980s led to the mass incarceration of young men of color [55]. These larger political occurrences were coupled with the cutting of community development block grants to cities from the 1980s to the 1990s [56]. Government support for social welfare has also steadily declined since the 1980s. According to Cnaan, Wineburg, and Boddie ([39], p. 279), "What started as contracting-out has become planned cuts in services, with the expectation that others will fill the gap left by the government's decreasing participation in social services provision." These shifts in public policy that have precipitated the disinvestment in black communities and social services have created a void that black churches are filling through their public engagement.

The most recent example of the government eschewing structural changes in favor of relying on the private sector - and potentially black churches - to address the problems facing black communities is President Barack Obama's “My Brother's Keeper" Initiative. Introduced in February 2014, President Obama unveiled this initiative to address the persistent opportunity gaps faced by young men of color. Although this initiative is aimed to help black, Latino, and Native American young men, the public faces of this initiative have mostly been those of young black men. In establishing the need for "My Brother's Keeper", Obama cited the lack of educational preparedness, low labor force participation rates, and likelihood to be victims of violence faced by young men of color. To improve the educational and life outcomes of young men of color, "My Brother's Keeper" relies on the private sector to provide mentorship, support networks, and skills. Faith communities, philanthropic organizations, and businesses are being called on to take up the charge of "My Brother's Keeper". Indeed, they have already responded and various companies such as AT\&T, AmeriCorps, and Citi Foundation have pledged millions of dollars in mentorship and tutoring programs and summer jobs. Although "My Brother's Keeper" has been criticized for overlooking the challenges faced by young women of color [57], a letter from a coalition of Christian black women leaders enthusiastically supports Obama's initiative and pledges their commitment, as black women, to help improve the lives of young men of color [58]. Because black churches have already been providing mentorship for young black men, these women recognize that "My Brother's Keeper", "allows for organizations, 
businesses, and entities, already working to improve the lives of boys and young men of color, to partner; and, allows citizens, with long-term interest and support, and those unaware of these disparaging facts, to work together to improve the statistics within their communities" [58]. The enthusiastic support expressed by these women is indicative of the potential support and labor black churches will likely give to this initiative. As further evidence of the potential support for "My Brother's Keeper" the Progressive National Baptist Convention ${ }^{5}$ has included the support of President Obama's initiative in their 2014 list of resolutions and they resolve to "support a partnership between government and the private sector intended to positively impact young African American men" ([60], p. 15). While it is still somewhat early to determine what programs, if any, black churches may establish in alignment with "My Brother's Keeper", there are clear indications that black churches are supportive of this initiative.

Second, I assert that black churches are among the few institutions providing race-specific remedies that have been abandoned in a colorblind era. Whether the rationale is that black advancement will only come through universal policies, or race is thought not to matter, there is an emphasis on race-neutral, universal policies intended to help everyone - particularly in the "age of Obama" [32]. The logic behind these universal policies is that what is good for the nation is good for minorities, rather than what is good for minorities is good for the nation. Yet, numerous scholars have asserted that a rising tide does not lift all boats, particularly if certain groups of people did not have boats to begin with (for examples see $[32,61,62]$ ). Black churches, which tend to be located in black communities, provide social services to those communities. Therefore, intentionally or not, they are targeting these communities with race-specific services. This has been true throughout the history of the Black Church in the United States. Where the government has explicitly refused to provide help or has provided a universal form of help, the Black Church has engaged in race-specific program development. In fact, the post-Reconstruction Black Baptist Church was overtly and explicitly nationalist in their self-help efforts and at the same time that the specific problems facing blacks were being addressed, the black National Baptist Convention worked to establish denominational hegemony free from white control [16].

To be clear, black churches providing race-specific initiatives does not mean that they deny assistance to non-blacks. But due to the segregation of religious institutions and neighborhoods, black churches primarily find themselves providing services to black constituents. For instance, Barnes [34] found that black megachurches are more likely to offer ministries and programs in response to social problems that disproportionately affect blacks. In her study, megachurches address problems such as incarceration, illiteracy, unemployment, poverty, healthcare, housing affordability-all of which disproportionately affect blacks - through reentry programs, literacy initiatives, employment and training, credit unions, food pantries, HIV/AIDS programs, health clinics, and low-cost housing developments. One such example of this is the Thr!ve Intern and Leadership Program founded in 2014 by Rev. Frederick D. Haynes III at Friendship-West Baptist Church in Dallas, Texas. Through this

\footnotetext{
The Progressive National Baptist Convention (PNBC) is a historically black denominational body. It was established in 1961 when a group of ministers from the National Baptist Convention (NBC) opposed the term limits of the NBC president and wanted to create a more socially active denomination that would support Dr. Martin Luther King, Jr. and the Civil Rights Movement [59].
} 
six-week internship program approximately 100 black men participate in leadership and job readiness programs, college tours, and mentorship [63]. Those young men selected for internships will work with 35 companies earning $\$ 10$ per hour, which is above the federal minimum wage. Rev. Haynes' program is characteristic of the type of programs President Obama would like to support through "My Brother's Keeper".

President Obama's "My Brother's Keeper" initiative also illustrates a plausible reliance on black churches to enact race-specific programming. President Obama has consistently endorsed universal, colorblind policies ${ }^{6}$ [32]. Yet, "My Brother's Keeper" is a race-specific initiative, which targets young men of color and the particular challenges they face such as dropping out of school, poverty, unemployment, violence, and incarceration. This initiative is a departure from the universal stance of the Obama administration and is undoubtedly needed. Nevertheless, it is critical to note that this initiative relies on donations and mentorship from the private sector rather than policy changes. It appears that the only way for the Obama administration to achieve race-specific programming is to follow the neoliberal model and rely on the private sector to enact it without the state providing any financial help. That "My Brother's Keeper" is an initiative proposed by the government, yet not financially supported by the government, reflects the limitations placed on the Obama administration to address racial inequality as well as the avoidance of race-specific government policies in a colorblind era. While the government has absolved itself of any financial support for "My Brother's Keeper", private organizations have pledged \$200 million over the next five years for programs associated with this initiative. Anticipating that there would be critics of a program that appears to be race specific, President Obama made it clear that "My Brother's Keeper" is not "some big, new government program" and that "government cannot play the only_or even the primary_role" [66]. Private organizations such as businesses and churches will assume the primary responsibility for executing "My Brother's Keeper". Given that black churches have already been doing the work of addressing some of these issues, it stands to reason that they will be actively involved in this race-specific initiative.

There is yet a second issue that is important to consider. While this initiative may help the odds of young men of color, due to the reliance on the private sector rather than changes in the policies that create the poor odds they face, it does nothing to "change the odds that (young men of color will) fall into a particular set of circumstances" [67]. The emphasis on personal responsibility and the need to "fix" young men of color does not change the conditions in which they live [57]. For example, providing mentorship to individual black males with the hope that they stay out of trouble is one strategy - that of "My Brother's Keeper". A completely different, and far more social justice oriented strategy, would be to change the laws and policing that support the prison industrial complex that incarcerates young black men at an alarming rate and then uses their label as "felons" to deny them

6 A prime illustration of Obama's race-neutral policies is his August 2012 interview with Black Enterprise Magazine. When asked about his response to critics who believe his administration has not done enough to support black businesses he said, 'I want all Americans to have opportunity. I'm not the president of black America. I'm the president of the United States of America." [64]. This has been the persistent stance of Obama's administration and is evidenced in an early 2009 interview where he stated, "The most important thing I can do for the African-American community is the same thing I can do for the American community, period, and that is get the economy going again and get people hiring again." [65]. 
basic rights to housing, employment, voting, and social services [55]. There are however, religious organizations involved in trying to create structural change by challenging the laws that contribute to the over-incarceration of young black men. For example, in April 2014, a group predominately composed of black religious leaders from various denominations issued a statement with policy suggestions aimed to eliminate the racial disparities in incarceration [68].

As outlined above in the history of black churches and public engagement, black churches have undertaken a variety of strategies to address racial inequality. Black pastors have sought elected government positions, black churches have established nonprofit community development corporations and challenged unjust laws, and black ministers have created theologies to raise consciousness and critique power structures, yet racial inequality remains. Some argue that despite the history of the Black Church, it should not be involved in the public sphere, as there should be a clear separation between church and state. Yet, as long as the country "calls upon the religious community to do more for the welfare of strangers" and continues to cut government social services, "church-state separation is merely an ideal" ([39], p. 301). To reiterate, I am not arguing that the Black Church is the only or best way to address racial inequality. The Black Church faces many challenges in a society that is characterized by deeply ingrained racial inequality. Among these challenges is that the Black Church suffers from the same inequalities it attempts to resist. As a voluntary organization composed of a racial group that has less income, wealth, education, and political power compared to whites, it is difficult for the Black Church to have the political capacity needed to address the social structures that cause racial inequality ${ }^{7}$. Yet, the continued growth and relevance of black churches suggests that scholars and popular critics rethink our expectations of the Black Church in understandings of and responses to racial inequality. It is unrealistic to think that the Black Church is capable of solving institutionalized racism or that we should assume that all black churches see this as part of their work. A more realistic perspective would examine both how black churches view the problem of racial inequality and how they see themselves addressing it.

\section{Conflicts of Interest}

The author declares no conflict of interest.

\section{References}

1. C. Eric Lincoln, and Lawrence Mamiya. The Black Church in the African American Experience. Durham: Duke University Press, 1990.

2. W.E.B. Du Bois. The Souls of Black Folk. Bensenville: Lushena Books, 1903.

3. E. Franklin Frazier. The Negro Church in America. New York: Schocken Books, 1963.

4. Gary T. Marx. Protest and Prejudice. New York: Harper \& Row, 1967.

5. Adolph Reed, Jr. The Jesse Jackson Phenomenon. New Haven: Yale University Press, 1986.

6. James H. Cone. Black Theology \& Black Power. Maryknoll: Orbis Books, 1969.

7. Gayraud S. Wilmore. Black Religion and Black Radicalism: An Interpretation of the Religious History of Afro-American People, 2nd ed. Maryknoll: Orbis Books, 1983.

\footnotetext{
7 I would like to thank one of the reviewers of this manuscript for this insight.
} 
8. Aldon Morris. The Origins of the Civil Rights Movement: Black Communities Organizing for Change. New York: Free Press, 1984.

9. Tamelyn Tucker-Worgs. The Black Megachurch: Theology, Gender, and the Politics of Public Engagement. Waco: Baylor University Press, 2011.

10. Sandra L. Barnes, and Oluchi Nwosu. "Black Church Electoral and Protest Politics from 2002 to 2012: A Social Media Analysis of the Resistance versus Accommodation Dialectic." Journal of African American Studies 18 (2013): 209-35.

11. Paul Harvey. Through the Storm, Through the Night: A History of African American Christianity. Lanham: Rowman \& Littlefield, 2011.

12. Phil Zuckerman, ed. Du Bois on Religion. New York: Alta Mira Press, 2000.

13. Gunnar Myrdal. American Dilemma: The Negro Problem and Modern Democracy. New York: Harper, 1944.

14. Edward L. Wheeler. Uplifting the Race: The Black Minister in the New South 1865-1902. New York: University Press of America, 1986.

15. Sarah A. Soule, and Nella van Dyke. "Black Church Arson in the United States, 1989-1996." Ethnic and Racial Studies 22 (1999): 724-42.

16. Evelyn Brooks Higginbotham. Righteous Discontent: The Women's Movement in the Black Baptist Church 1880-1920. Cambridge: Harvard University Press, 1993.

17. Hans A. Baer, and Merrill Singer. African-American Religion: Varieties of Protest and Accommodation, 2nd ed. Knoxville: University of Tennessee Press, 2002.

18. Booker T. Washington. "The Religious Life of the Negro." The North American Review 181 (1905): 20-23.

19. James C. Scott. Domination and the Arts of Resistance. New Haven: Yale University Press, 1990.

20. Jonathan Walton. Watch This! The Ethics and Aesthetics of Black Televangelism. New York: New York University Press, 2009.

21. Kelly Brown Douglass. Sexuality and the Black Church: A Womanist Perspective. Maryknoll: Orbis Books, 1999.

22. Jacquelyn Grant. White Women's Christ and Black Women's Jesus: Feminist Christology and Womanist Response. Atlanta: Scholars Press, 1989.

23. Tamelyn Tucker-Worgs, and Donn C. Worgs. "Black Morality Politics: Preachers, Politicians, and Voters in the Battle over Same-Sex Marriage in Maryland." Journal of Black Studies 45 (2014): 338-62.

24. Delores Williams. Sisters in the Wilderness: The Challenge of Womanist God-Talk. Maryknoll: Orbis Books, 1993.

25. Joseph R. Washington, Jr., ed. Black Religion and Public Policy. Philadelphia: privately printed, 1978.

26. Albert J. Raboteau. Slave Religion: The "Invisible Institution" in the Antebellum South. New York: Oxford University Press, 2004.

27. Jeremiah Wright, Jr. "An Underground Theology." In Black Faith and Public Talk: Critical Essays on James H. Cone's Black Theology and Black Power. Edited by Dwight Hopkins. Waco: Baylor University Press, 2007, pp. 96-102. 
28. Darlene C. Hine, William C. Hine, and Stanley Harrold. The African-American Odyssey, 3rd ed. Upper Saddle River: Pearson Education, Inc., 2006.

29. C. Eric Lincoln. Race, Religion, and the Continuing American Dilemma, 2nd ed. New York: Hill and Wang, 1999.

30. Adolph Reed, Jr., ed. Without Justice for All: The New Liberalism and Our Retreat from Racial Equality. Boulder: Westview Press, 1999.

31. Manning Marable. Malcolm X: A Life of Reinvention. New York: Viking, 2011.

32. Fredrick C. Harris. The Price of the Ticket: Barack Obama and Rise and Decline of Black Politics. New York: Oxford University Press, 2012.

33. Allison Calhoun-Brown. "Upon This Rock: The Black Church, Nonviolence, and the Civil Rights Movement." PS: Political Science and Politics 33 (2000): 168-74.

34. Sandra Barnes. "Black Megachurches: Social Gospel Usage and Community Empowerment." Journal of African American Studies 15 (2010): 177-98.

35. Anthony Pinn. What Has the Black Church to Do with Public Life? New York: Palgrave McMillan, 2013.

36. E. Franklin Frazier, and C. Eric Lincoln. The Negro Church in America. The Black Church since Frazier. New York: Schocken Books, 1974.

37. Sara E. Stoutland. "Community Development Corporations: Mission, Strategy and Accomplishments." In Urban Problems and Community Development. Edited by Ronald F. Ferguson and William T. Dickens. Washington: Brookings Institution Press, 1999, pp. 193-240.

38. José Casanova. Public Religions in the Modern World. Chicago: University of Chicago Press, 1994.

39. Ram A. Cnaan, Robert J. Wineburg, and Stephanie C. Boddie. The Newer Deal: Social Work and Religion in Partnership. New York: Columbia University Press, 1999.

40. Jason Hackworth. Faith Based: Religious Neoliberalism and the Politics of Welfare in the United States. Athens: University of Georgia Press, 2012.

41. Peter L. Berger, and Richard John Neuhaus. To Empower People: The Role of Mediating Structures in Public Policy. Washington: American Enterprise Institute, 1977.

42. Mark Chaves. "Religious Congregations and Welfare Reform: Who Will Take Advantage of 'Charitable Choice'?” American Sociological Review 64 (1999): 836-46.

43. Fredrick C. Harris. "Black Churches and Civic Traditions: Outreach, Activism, and the Politics of Public Funding of Faith-Based Ministries.” In Can Charitable Choice Work? Covering Religion's Impact on Urban Affairs and Social Services. Edited by Andrew Walsh. Hartford: Trinity College, 2001, pp. 140-56.

44. Martin Gilens. Why Americans Hate Welfare: Race, Media, and the Politics of Antipoverty Policy. Chicago: University of Chicago Press, 1999.

45. Ange-Marie Hancock. The Politics of Disgust: The Public Identity of the Welfare Queen. New York: New York University Press, 2004.

46. Eddie S. Glaude, Jr. "Of the Black Church and the Making of a Black Public." In African American Religious thought: An Anthology. Edited by Cornell West and Eddie Glaude, Jr. Louisville: Westminister John Knox Press, 2003, pp. 338-65.

47. Raphael Warnock. The Divided Mind of the Black Church: Theology, Piety, and Public Witness. New York: New York University Press, 2014. 
48. C. Eric Lincoln, and Lawrence Mamiya. "Challenges to the Black Church: The Black Church in the Twenty-First Century." In Yearbook of American and Canadian Churches. Edited by Kenneth B. Bedell. Nashville: Abingdon, 1993, pp. 1-7.

49. Michael Leo Owens. "Contestant, Advocate, Implementer: Social Services and the Policy Roles of African American Churches." In Long March Ahead: African American Churches and Public Policy in Post-Civil Rights America. Edited by R. Drew Smith. Durham: Duke University Press, 2004, pp. 73-102.

50. Mark Chaves. Congregations in America. Cambridge: Harvard University Press, 2004.

51. Karen J. Gibson. "Bleeding Albina: A History of Community Disinvestment, 1940-2000." Transforming Anthropology 15 (2007): 3-25.

52. Douglas S. Massey, and Nancy A. Denton. American Apartheid: Segregation and the Making of the Underclass. Cambridge: Harvard University Press, 1993.

53. William Julius Wilson. The Truly Disadvantaged: The Inner City, the Underclass, and Public Policy. Chicago: University of Chicago Press, 1987.

54. Gary Orfield. Schools More Separate: Consequences of a Decade of Resegregation. Cambridge: Harvard University, 2001.

55. Michelle Alexander. The New Jim Crow: Mass Incarceration in the Age of Colorblindness. New York: New Press, 2010.

56. Timothy J. Conlan. From New Federalism to Devolution: Twenty-Five Years of Intergovernmental Reform. Washington: Brookings Institute, 1998.

57. Kimberlé Williams Crenshaw. "The Girls Obama Forgot." The New York Times, 29 July 2014.

58. AprilDRyan. com. "National Women Leadership Supporting My Brother's Keeper.” Available online: http://aprildryan.com/2014/06/30/national-women-leadership-supporting-my-brothers-keeperinitiative/ (accessed on 23 August 2014).

59. Anthony Pinn. The African American Religious Experience in America. Westport: Greenwood Press, 2006.

60. Carroll A. Baltimore. PNBC Resolutions 2014. Washington: Progressive National Baptist Convention, 2014.

61. Lani Guinier, and Gerald Torres. The Miner's Canary: Enlisting Race, Resisting Power, Transforming Democracy. Cambridge: Harvard University Press, 2002.

62. Kimberlé Williams Crenshaw. "Twenty Years of Critical Race Theory: Looking Back to Move Forward." Connecticut Law Review 43 (2011): 1253-352.

63. The Dallas Moring News. "Dallas Internship Program Introduces Young Black Men to Careers." Available online: http://www.dallasnews.com/news/metro/20140628-dallas-internship-programintroduces-young-black-men-to-careers.ece (accessed on 7 October 2014).

64. Derek T. Dingle "Oval Office Interview with President Barack Obama." Black Enterprise, 6 August 2012.

65. Justin Hyde, and Richard Wolf. "President Obama Says He Won't Put Focus on Blacks' Troubles." USA Today, 3 December 2009.

66. The Whitehouse. "Remarks by the President on 'My Brother's Keeper' Initiative." Available online: http://www.whitehouse.gov/the-press-office/2014/02/27/remarks-president-my-brotherskeeper-initiative (accessed on 24 August 2014). 
67. Jamelle Bouie. "The Flaw in My Brother's Keeper." The Daily Beast, 27 February 2014. Available online: http://www.thedailybeast.com/articles/2014/02/27/the-flaw-in-my-brother-skeeper.html (accessed on 23 August 2014).

68. We are the Drug Policy Alliance. "Religious Leaders Release 'Easter Statement' Calling for an End to the War on Drugs and Mass Incarceration.” Available online: http://www.drugpolicy.org/ news/2014/04/religious-leaders-release-easter-statement-calling-end-war-drugs-and-massincarceration (accessed on 11 December 2014).

(C) 2015 by the author; licensee MDPI, Basel, Switzerland. This article is an open access article distributed under the terms and conditions of the Creative Commons Attribution license (http://creativecommons.org/licenses/by/4.0/). 